\title{
When the Messenger Is More Important Than the Message: An Experimental Study of Evidence Use in Francophone Africa
}

\author{
Amandine Fillol ( $\nabla$ amandine.fillol@hotmail.fr) \\ Universite de Montreal Ecole de Sante Publique https://orcid.org/0000-0003-2395-8185 \\ Esther Mc Sween-Cadieux \\ Université de Sherbrooke Faculté d'Éducation: Universite de Sherbrooke Faculte d'education \\ Bruno Ventelou \\ Centre National de la Recherche Scientifique \\ Marie-Pier Larose \\ University of Turku: Turun Yliopisto \\ Ulrich Boris Nguemdjo Kanguem \\ Aix-Marseille School of Economics: Aix-Marseille Sciences Economiques

\section{Kadidiatou Kadio} \\ Institut de Recherche en Sciences de la Santé: Institut de Recherche en Sciences de la Sante \\ Christian Dagenais \\ University of Montreal Department of Psychology: Universite de Montreal Departement de psychologie

\section{Valéry Ridde} \\ Institut de recherche pour le développement: Institut de recherche pour le developpement
}

\section{Research}

Keywords: Global health, policy briefs, Structural drivers, COVID-19, Power

Posted Date: February 7th, 2022

DOI: https://doi.org/10.21203/rs.3.rs-1178312/v2

License: (c) (i) This work is licensed under a Creative Commons Attribution 4.0 International License. Read Full License 


\section{Abstract}

Background: Epistemic injustices are increasingly decried in global health. This study aims to investigate whether the source of knowledge influences the perception of that knowledge and the willingness to use it in francophone African health policy-making context.

Methods: The study followed a randomized experimental design in which participants were randomly assigned to one of seven policy briefs that were designed with the same scientific content but with different organizations presented as authors. Each organization was representative of financial, scientific, or moral authority. For each type of authority, two organizations were proposed: one North American or European, and the other African.

Results: The initial models show that there was no significative association between the type of authority and the location of the authoring organization and the two outcomes (perceived quality and reported instrumental use). Stratified analyses highlighted that policy briefs signed by the North American/European donor organization were perceived to be of lower quality than policy briefs signed by the African donor organization. For both perceived quality and reported instrumental use, these analyses found that policy briefs signed by the North American/European university were associated with higher scores than policy briefs signed by the African university whereas policy briefs signed by the North American/European regional office or international organization were associated with lower score than those signed by the African regional office of the international organization.

Conclusion: The results confirm the significant influence of sources on perceived global health knowledge and the intersectionality of sources of influence. This analysis allows us to learn more about organizations in global health leadership, and to reflect on the implications for knowledge translation practices.

\section{Introduction}

Epistemic power issues are increasingly decried in global health (1-5). Indeed, legitimation of knowledge is driven by economically dominant individuals or organizations (5-8) and elites guiding global decisions (9). Going beyond traditional issues of social, material, and geographic inequalities to explain these processes, Bhakuni and Abimbola (10) recently highlighted epistemic injustices in global health. Epistemic injustice was first defined by Fricker (11) as a wrong done to someone in his or her capacity as a knower. She described two types of epistemic injustice: testimonial and hermeneutical. First, testimonial injustice consists of discrediting the knowledge provided by someone due to the listener's prejudices about his or her social characteristics. For example, during the Ebola epidemic in 2014, Lauer (12) highlighted how African experts were discredited by outside speakers and international actors. During the COVID-19 pandemic, Dalglish (13) decried "the lies given to global health expertise", as there was a lack of recognition of African and Asian countries' proactivity in handling the crisis. Hermeneutical injustice is the impossibility that someone interpretation of a social phenomenon is recognized due to the lack of recognition of his or her worldview by dominant groups. Bhakuni et Abimbola (10) called it interpretative injustice. For example, Lauer (12) explained that during the 2014 Ebola crisis, in North America, a strike in Sierra Leone was interpreted and mediated as the consequence of the selfish behavior of health professionals rather than a manifestation against some health center privatization by British expatriates. This mediatization contributed to devaluing the credibility of health professionals who participated in legitimate international interventions. While these two kinds of injustices are strongly related, the analysis we offer in this article aims to study testimonial injustice in global health. To our knowledge, no study has been conducted to identify which testimonial injustices exist in global health.

A study carried out in Spain highlighted that credibility attributed to a scientific document differed depending on the organizations indicated as the authors (14). In another study conducted on the YouTube platform, the perceived integrity and benevolence of the presenter of a science video had a significant influence on the perceived credibility of the information presented (15). Furthermore, in another study, if the author was considered an authority in the relevant industry, then the reader was more likely to act on what was said in the document (16). In this case, the presence of the author's opinion also promoted a willingness to act or share information (16). While scientists are supposed to be more experienced in dealing with issues of credibility of knowledge, it has been shown that they place more importance on "who is talking" rather than "what is being said" (17). In global health, there is a growing confusion between scientific, expert, moral and financial authorities. For example, institutions with financial authority manage to legitimize knowledge and thus acquire an authority of expertise (18, 19). At the same time, international organizations that are supposed to represent moral authorities are losing their credibility. The World Health Organization (WHO), for example, has been criticized for the influence of major donors in its decisions and for the confusion between different functions, notably between technical and political mandates $(20,21)$. In addition, the lack of social diversity in international decision-making bodies as well as in academia, with an over-representation of men from North America or Europe, contributes to some voices not being heard. This lack of representativeness leads to interpretative and testimony epistemic injustices (22-26). Testimony injustice, which often occurs toward minorities, are the product of ones from low-income countries as much as ones from high-income countries (27).

Francophone Africa is particularly representative of global health complexity as the institutional landscape is composed of several actors from different sectors and countries involved in health policy. There are few studies dealing with epistemic injustices in this region even though

Page 2/17 
knowledge production and utilization are strongly influenced by power issues and colonization history $(1,10,12,26,28,29)$. To our knowledge, there are no quantitative studies in this field that allow us to observe the effects of the source of a document on the perception of the quality of knowledge or with the intention to use it. As global health brings together actors from different sectors, countries, and disciplines to offer solutions to health problems in the context of globalization, knowledge dissemination and translation are key mandates of global health stakeholders. Thus, the purpose of this research is to investigate whether the source of knowledge influences the perception of that knowledge and the willingness to use it for global health stakeholders in francophone Africa.

\section{Present study}

To conduct this research, we used a specific tool: the policy brief. Policy briefs are increasingly used to disseminate scientific findings to inform policy-makers of the best available knowledge (30). A policy brief is "a concise document that prioritizes a particular policy issue and presents the evidence in nontechnical language and without professional jargon" (16). The existing guides to support their design are quite varied, and few studies exist on their effectiveness (31).

Our main outcomes are perceived quality and reported instrumental use. First, credibility, while much studied, is not the only quality attributed to knowledge that would improve its use. The visual aspect, the relevance of information and the recommendations in relation to local realities have been described as favorable to policy briefs' effectiveness (31). Perceived legitimacy, relevance and understanding are also qualities to be considered to improve the links between science, action and policy (32-34).

Use of knowledge is usually developed into three subcategories: i) symbolic use which aims to rely on, quote or argue from knowledge to legitimize a choice or a decision, ii) conceptual use which is an increase in knowledge about a subject or issue and evolution in the understanding of it and iii) instrumental use which is associated with a change in practice or opinion (35, 36). We chose to focus on instrumental use as it is a concrete application of knowledge use for policy-making (37).

Therefore, this research aims to investigate whether the source of a policy brief influence not only its perceived credibility but also its perceived quality (visual appearance, relevance, legitimacy, and comprehensibility) and reported instrumental use of knowledge in francophone African health policy-making context.

\section{Conceptual framework}

To categorize the different sources, we borrow the typology of diffusion entrepreneur authorities (38): financial, scientific, expertise and/or moral authority. To study the effects of the sources of a policy brief, we chose to use organizations representing different authorities as authors: i) donor organizations for financial authority, ii) universities for scientific authority and, iii) international organizations for moral authority. A typical organization representing expertise authority is more difficult to find, which is why we have limited ourselves to these three authorities. We also differentiated the authorities according to their geographical location (North America or Europe versus Africa) because many studies attest to the scientific hegemony of North America or Europe $(12,25,29,39,40)$, especially in francophone Africa where these countries have a strong presence in the health landscape.

\section{Objectives and hypotheses}

Our main objectives were to study : i) whether the type of authorities (financial, scientific, moral) of the authoring organization of a policy brief is associated with perceived quality and reported instrumental use, ii) whether the location (North America or Europe versus Africa) of the authoring organization of a policy brief is associated with perceived quality and reported instrumental use and, iii) how the location of these authorities interact with the type of authority in the prediction of perceived quality and reported instrumental use. We hypothesized that authorities from North America or Europe countries would be associated with higher levels of perceived quality and reported instrumental use $(12,29,39,41,42)$. However, we did not have any hypothesis in regard to the influence of the types of authorities and the interaction between types of authorities and location. These analyses were exploratory considering the lack of previous research on the topic among global health francophone African stakeholders.

\section{Methods Study design}

The study follows a randomized experimental design in which participants were randomly assigned to one of seven policy briefs that were designed with the same scientific content and visual features; only the authoring organizations were different. One of them contained no authoring organization.

The study was conducted remotely in three stages using a website specifically created for the study purpose (Wix website). A computer version and a mobile version were produced. First, the participant completed a first questionnaire. Second, the participant was randomly assigned to a 
policy brief that he or she had to read. The random distribution of the document was achieved using a programming code in html language in a window of the site (the code is available on request). Third, after reading the document, the participant completed a second questionnaire.

Participants

To be as representative as possible, we have used the nine categories of global health actors proposed by Hoffman and Cole (2018) to target the study participants : i) national governments, ii) United nations entities and international organizations, iii) development banks, iv) public/private partnerships, v) philanthropic organizations, vi) global civil society and nongovernmental organizations, vii) private industries, viii) professional associations, and ix) academic institutions. The countries involved in our study were French-speaking African countries (Benin, Burkina Faso, Chad, Guinea, Mali, Mauritania, Niger, Senegal, and Togo) and the main countries involved in development assistance in this region (Belgium, Canada, France, and Switzerland). Participants were contacted through our professional networks and through focal points in the countries or organizations. Mailing lists and thematic groups on the links between science, policy and health were also used. Data collection was conducted from January to March 2021. We conducted exploratory analyses to determine if we had enough participants and chose to stop data collection because of preliminary results that allowed for relevant analyses.

\section{Intervention}

The intervention is the assignment of a policy brief where only the name and logo of the main author vary. To make the study as close to reality as possible, we used an existing policy brief (additional files 1 and 2). These were the results of a scoping review and recommendations related to the effectiveness of containment measures for vector-borne diseases and other emerging and re-emerging infectious diseases.

\section{Measures}

\section{Main outcomes}

The two main outcomes are the perceived quality of knowledge and its reported instrumental use. Questionnaires are available in additional file 3.

\section{Perceived quality of knowledge}

The perceived quality of knowledge was measured through a set of statements $(n=10)$ for which participants have expressed their level of agreement (Table 1). We identified complementary ways of considering the perceived quality of knowledge in the literature: visual appearance, credibility, legitimacy, relevance, and comprehension. We, therefore, defined several statements to measure each of these constructs, thanks to studies already conducted on credibility $(15,44-47)$, legitimacy $(48)$ and the visual aspect, relevance and understanding of the brief (16, 4951). For example, the following statement was offered to participants: "The content of the document is relevant to my work" and participants responded on a five-point Likert scale: "Strongly Disagree," "Disagree," "Agree," "Somewhat Agree," "Strongly Agree," or "Do not know or do not want to answer." This last option was considered missing data in further analyses. We then assessed whether the set of statements allowed us to calculate an overall quality score. After examining the inter-item correlations and the distribution of each item, we calculated an overall perceived knowledge quality score by averaging the 10 statements (from 1 to 5 ). Cronbach's alpha, which measures the internal consistency of the constructs in measuring the perceived quality score, was 0.88 .

\section{Reported instrumental use of knowledge}

Self-reported instrumental knowledge use was measured through a set of statements $(n=3)$ for which participants estimated the probability that they would perform different actions (Table 1). For example, they were asked, "Change my opinion on the effectiveness of measures to control infectious disease outbreaks " and they responded on a five-point Likert scale: "Not at all likely", "Unlikely", "Likely", "Somewhat likely", "Very likely", and "Do not know or do not want to answer". This last option was considered missing data in further analyses. We proposed three items on changes in opinion, policy, and practice. We then assessed whether the set of statements allowed us to calculate a score of reported instrumental use. After examining inter-item correlations and the distribution of each item, we calculated a score of reported instrumental knowledge use by averaging 3 statements (from 1 to 5 ; Cronbach's alpha was equal to 0.78 ). 
Table 1

Summary of variables to be measured and statements used

\begin{tabular}{|c|c|c|}
\hline Outcomes & Dimensions & Statements \\
\hline \multirow[t]{10}{*}{ Perceived quality } & Relevance & "The content of the document is relevant to my work." \\
\hline & \multirow[t]{2}{*}{ Legitimacy } & "The content of the paper is consistent with my professional value." \\
\hline & & "The content of the paper seems to take into account a range of views and not just the author's." \\
\hline & \multirow[t]{3}{*}{ Credibility } & "The level of detail provided in the document is appropriate." \\
\hline & & "The methodology presented in the document appears robust." \\
\hline & & "The rationale presented in the document leading to the recommendations is convincing." \\
\hline & \multirow[t]{2}{*}{ Visual aspect } & "The visual presentation of the document is attractive." \\
\hline & & "The length of the document is adequate." \\
\hline & \multirow[t]{2}{*}{ Comprehension } & "The content of the document is easy to understand." \\
\hline & & "The proposed recommendations are clear." \\
\hline \multirow[t]{3}{*}{$\begin{array}{l}\text { Reported } \\
\text { Instrumental Use }\end{array}$} & & $\begin{array}{l}\text { "Change my opinion on the issue of the effectiveness of measures to contain infectious disease } \\
\text { outbreaks." }\end{array}$ \\
\hline & & $\begin{array}{l}\text { "Change my current policies or practices regarding the topic of containment measures to contain } \\
\text { infectious disease outbreaks." }\end{array}$ \\
\hline & & $\begin{array}{l}\text { "Develop or sponsor new studies on the topic of containment measures to contain infectious } \\
\text { disease outbreaks." }\end{array}$ \\
\hline
\end{tabular}

\section{Cofounding variables}

The following were considered cofounding variables: prior knowledge about the topic of the policy brief before and after reading the policy brief (6 questions), knowledge and opinion about the organization presented as the policy brief author (6 questions) and sociodemographic, professional, geographic, and migratory characteristics of the participants (10 questions).

\section{Analyses}

\section{Descriptives analyses}

Descriptive analyses were conducted to observe the diversification of the sample and the distribution of treatments among participants and the main outcomes (perceived quality and reported uses).

\section{Main analyses}

Are the type of authorities (financial, scientific and moral) and the location (North America or Europe versus Africa) of the authoring organization of a policy brief associated with perceived quality and reported instrumental use?

We conducted linear regression models to observe whether type of authorities (financial, scientific and moral) and location of the authoring organization were associated with our outcomes (i.e., perceived quality and reported instrumental use). We estimated our outcomes separately in two different models, but type of authorities and location of the authoring organization were entered in the same model as we aim to study the unique contribution of each factor. Professional characteristics (perceived autonomy and experience), gender, occupational sector, level of the last degree obtained and region where the last degree was obtained were systematically included to the models as covariates even when they were not significant, as they are among the socioprofessional factors that are strongly related to the research question (16). Knowing or not knowing the authoring organization was also included as a covariate. We believe that knowledge of the organization is a potential intervening variable that can explain the relationships between the authoring organization and the different dependent variables.

How the type of authority (financial, scientific and moral) of authoring organization interacts with the location of these authorities (North America or Europe versus Africa) in the prediction of perceived quality and reported instrumental use?

First, we added an interaction term to our previous linear regression models between the type of authority and the location of these authorities' variables. We tested separately, in two different model, these interactions in relation to perceived quality and reported instrumental use. When we detected a significant interaction at the $10 \%$ significance level, we carried out stratified analyses where we regressed the location of the 
authorities on the perceived quality and reported instrumental use according to the type of authority of the authoring organizations (financial, scientific, moral).

\section{Results}

\section{Descriptive analyses}

\section{Participants' characteristics}

The sample consisted of 233 participants, the majority of whom were aged between 26 and 45 years (64\%, n=148/233) and male (68\%, $n=159 / 233)$. The majority had a graduate degree $(88 \%, n=205 / 233)$. The professions represented were mainly project leaders, managers, or coordinators $(30 \%, n=70 / 233)$, researchers $(24 \%, n=57 / 233)$ and health professionals $(18 \%, n=43 / 233)$. Their experience ranged from 0 to over 25 years. Regarding geographic distribution, the main birthplaces were France (23\%, n=54/233), Mali (15\%, n=35/233), Burkina Faso (11\%, $n=25 / 233)$ and Benin $(10 \%, n=22 / 233)$. For education, the main places where the highest degree was obtained were France $(35 \%$, $n=82 / 233)$ or Mali $(10 \%, n=24 / 233)$. More than one third of the participants were born, educated, and lived in West or Central Africa (36\%, $n=88 / 233)$, and less than a fifth were born, educated, and lived in Europe or North America (16\%, $n=39 / 233)$. A small percentage of participants (13\%, $n=31 / 233)$ were born and resided in West or Central Africa and obtained their highest degree in Europe or North America. Finally, less than one tenth (8\%, $\mathrm{n}=20 / 233$ ) were born and graduated with their highest degree in Europe or North America and lived in West or Central Africa at the time of the survey. A detailed description of the participants is presented in additional file 4.

\section{Outcomes' description}

Participants rated the policy brief as adequate in terms of quality (mean: 3.909, standard deviation: 0.687). In terms of reported instrumental use, participants mainly reported that they would be likely to use the policy brief (mean: 3.379, standard deviation: 1.024). A detailed description of outcomes is presented in additional file 5.

\section{Main analyses}

Are the type of authority and the location of the authoring organization of a policy brief associated with knowledge perceived quality?

An initial model found that perceived quality was not significantly associated with the type of authority and the location of the authoring organization. Knowledge of the organization was not significantly associated with the perceived quality score.

Quality was perceived to be of higher for participants with a graduate level of education compared to participants with a postgraduate level of education $(\beta=0.424,95 \% \mathrm{Cl}=0.078$ to $0.770, p=0.017)$ and for participants who graduated from North America/Europe compared to those who graduated from Africa $(\beta=-0.436,95 \% \mathrm{Cl}=-0.787$ to $-0.085, p=0.015)$ (Table 2). 
Table 2

Associations between location of authoring organization and perceived quality of knowledge.

\begin{tabular}{|c|c|c|c|c|c|c|}
\hline & \multicolumn{5}{|c|}{ Perceived quality } & \multirow[b]{2}{*}{$P$ value } \\
\hline & $\beta$ & {$[95 \% \mathrm{Cl}]$} & & & & \\
\hline Intercept & 0.285 & {$[\quad-0.574$} & ; & 1.143 & ] & 0.513 \\
\hline \multicolumn{7}{|l|}{ Type of authority of authoring organization } \\
\hline University (scientific authority) & REF & REF & & REF & & REF \\
\hline Donor organization (financial authority) & 0.100 & {$[\quad-0.288$} & ; & 0.488 & ] & 0.610 \\
\hline International Organization (moral authority) & -0.155 & {$[\quad-0.540$} & ; & 0.231 & ] & 0.430 \\
\hline \multicolumn{7}{|l|}{ Location of authoring organization } \\
\hline Africa & REF & REF & & REF & & REF \\
\hline Europe or North America & -0.033 & {$[\quad-0.342$} & ; & 0.275 & ] & 0.830 \\
\hline \multicolumn{7}{|l|}{ Confounding variable } \\
\hline \multicolumn{7}{|l|}{ Prior knowledge of the organization } \\
\hline Knows the organization & REF & REF & & REF & & REF \\
\hline Does not know the organization & -0.269 & {$\left[\begin{array}{ll}{[} & -0.683\end{array}\right.$} & ; & 0.146 & ] & 0.202 \\
\hline Perceived autonomy in the profession & 0.027 & {$\left[\begin{array}{ll}{[} & -0.100\end{array}\right.$} & ; & 0.154 & ] & 0.680 \\
\hline Experience in the profession & -0.101 & {$\left[\begin{array}{ll}{[} & -0.251\end{array}\right.$} & ; & 0.049 & ] & 0.185 \\
\hline \multicolumn{7}{|l|}{ Gender } \\
\hline Female & REF & REF & & REF & & REF \\
\hline Male & 0.124 & {$\left[\begin{array}{ll}-0.204 \\
\end{array}\right.$} & ; & 0.453 & ] & 0.456 \\
\hline \multicolumn{7}{|l|}{ Profession } \\
\hline Research professionals & REF & REF & & REF & & REF \\
\hline Health professionals & 0.293 & {$\left[\begin{array}{ll}{[} & -0.223\end{array}\right.$} & ; & 0.809 & ] & 0.263 \\
\hline Coordination/management of programs & 0.088 & {$[\quad-0.317$} & ; & 0.492 & ] & 0.668 \\
\hline Other & 0.214 & {$[\quad-0.252$} & ; & 0.679 & ] & 0.366 \\
\hline \multicolumn{7}{|l|}{ Level of study } \\
\hline University level postgraduate (PhD) & REF & REF & & REF & & REF \\
\hline University level less than or equal to 1 st cycle & 0.319 & {$[\quad-0.166$} & ; & 0.804 & ] & 0.195 \\
\hline University level 2nd cycle (MD) & 0.424 & {$[0.078$} & ; & 0.770 & ] & $0.017 *$ \\
\hline \multicolumn{7}{|l|}{ Region of graduation } \\
\hline Africa & REF & REF & & REF & & REF \\
\hline Europe or North America & -0.436 & {$[\quad-0.787$} & ; & -0.085 & ] & $0.015^{*}$ \\
\hline
\end{tabular}

Are the type of authority and the location of the authoring organization of a policy brief associated with reported instrumental use?

An initial model found that perceived quality was not significantly associated with the type of authority and the location of the authoring organization. Knowledge of the organization was not significantly associated with the perceived quality score.

Male participants reported more instrumental use than female participants $(\beta=0.322,95 \% \mathrm{Cl}=0.012$ to $0.632, p=0.042)$, as well as health professionals compared to research professionals $(\beta=0.542,95 \% \mathrm{Cl}=0.055$ to $1,030, \mathrm{p}=0.042)$, and participants with an undergraduate or graduate level of education compared to those with a postgraduate level of education (respectively $\beta=0.542,95 \% \mathrm{Cl}=0.084$ to $1.000, p=0.021$ 
and $\beta=0.336,95 \% \mathrm{Cl}=0.010$ to $0.663, \mathrm{p}=0.044)$. Participants who graduated from Europe or North America reported less instrumental use than those who graduated from Africa $(\beta=-0.739,95 \% \mathrm{Cl}=-1.071$ to $-0.408, \mathrm{p}<0.001)$ (Table 3 ).

Table 3

Associations between authoring organization and reported instrumental use of knowledge.

\begin{tabular}{|c|c|c|c|c|c|}
\hline & \multicolumn{5}{|c|}{ Reported instrumental use } \\
\hline & $\beta$ & {$[95 \% \mathrm{Cl}]$} & & & $P$ value \\
\hline Intercept & -0.469 & {$\left[\begin{array}{ll}-1.280 \\
-1\end{array}\right.$} & 0.342 & ] & 0.255 \\
\hline \multicolumn{6}{|l|}{ Intervention } \\
\hline \multicolumn{6}{|l|}{ Type of authority of authoring organization } \\
\hline University (scientific authority) & REF & REF & REF & & REF \\
\hline Donor organization (financial authority) & 0.128 & {$\left[\begin{array}{ll}0.239 \\
-1\end{array}\right.$} & 0.494 & ] & 0.492 \\
\hline International Organization (moral authority) & 0.289 & {$\left[\begin{array}{ll}0.075 \\
-1\end{array}\right.$} & $; \quad 0.654$ & ] & 0.119 \\
\hline \multicolumn{6}{|l|}{ Location of authoring organization } \\
\hline Africa & REF & REF & REF & & REF \\
\hline Europe or North America & 0.083 & {$[\quad-0.208$} & ; $\quad 0.374$ & ] & 0.573 \\
\hline \multicolumn{6}{|l|}{ Confounding variable } \\
\hline Prior knowledge of the organization & REF & REF & REF & & REF \\
\hline Knows the organization & -0.145 & {$\left[\begin{array}{ll}0.536 \\
-1\end{array}\right.$} & 0.247 & ] & 0.466 \\
\hline \multicolumn{6}{|l|}{ Does not know the organization } \\
\hline Perceived autonomy in the profession & 0.075 & {$\left[\begin{array}{ll}-0.045 \\
-1\end{array}\right.$} & 0.195 & ] & 0.218 \\
\hline Experience in the profession & 0.017 & {$\left[\begin{array}{ll}-0.125 \\
-12\end{array}\right.$} & 0.158 & ] & 0.818 \\
\hline \multicolumn{6}{|l|}{ Gender } \\
\hline Female & REF & REF & REF & & REF \\
\hline Male & 0.322 & {$[0.012$} & ; $\quad 0.632$ & ] & $0.042 *$ \\
\hline \multicolumn{6}{|l|}{ Profession } \\
\hline Research professionals & REF & REF & REF & & REF \\
\hline Health professionals & 0.542 & {$[0.055$} & $; \quad 1.030$ & ] & $0.029 *$ \\
\hline Coordination/management of programs & 0.046 & {$\left[\begin{array}{ll}0.336 \\
-1\end{array}\right.$} & 0.428 & ] & 0.812 \\
\hline Other & 0.079 & {$\left[\begin{array}{ll}-0.361 \\
-1\end{array}\right.$} & ; $\quad 0.519$ & ] & 0.722 \\
\hline \multicolumn{6}{|l|}{ Level of study } \\
\hline University level postgraduate (PhD) & REF & REF & REF & & REF \\
\hline University level less than or equal to 1 st cycle & 0.542 & {$[0.084$} & $; \quad 1.000$ & ] & $0.021 *$ \\
\hline University level 2nd cycle (MD) & 0.336 & {$[0.010$} & $; \quad 0.663$ & ] & $0.044^{*}$ \\
\hline \multicolumn{6}{|l|}{ Region of graduation } \\
\hline Africa & REF & REF & REF & & REF \\
\hline Europe or North America & -0.739 & {$\left[\begin{array}{ll}-1.071 \\
0\end{array}\right.$} & -0.408 & ] & $0,000 *$ \\
\hline
\end{tabular}

How the type of authority of authoring organization interacts with the location of these authorities in the prediction of perceived quality?

We found that the interaction between donor organizations and location was significant $(\beta=-1.547,95 \% \mathrm{Cl}=-2.228$ to $-0.867, \mathrm{p}<0.001)$ as well as that between universities and location $(\beta=-1.518,95 \% \mathrm{Cl}=-2.217$ to $-0.819, \mathrm{p}<0.001)$. Therefore, we performed a stratified analysis by type of authority of the authoring organization. 
The first stratified model revealed that perceived quality was lower for participants who received policy briefs signed by the North American/European donor organization than for those who received policy briefs signed by the African donor organization $(\beta=-0.561,95 \% \mathrm{Cl}=$ -.0968 to $-0.155, \mathrm{p}=0.008$ ) (Table 4).

\section{University}

The second stratified model revealed that perceived quality was stronger for participants who received policy briefs signed by the North American/European university than for those who received policy briefs signed by the African university $(\beta=-0.879,95 \% \mathrm{Cl}=0.462$ to 1.295 , $\mathrm{p}<0.001)$ (Table 4).

International organization

The third stratified model revealed that perceived quality was lower for participants who received the policy briefs signed by the North American/European regional office of the international organization compared to those who received the policy briefs signed by the African regional office of the international organization $(\beta=-0.688,95 \% \mathrm{Cl}=-1.287$ to $-0.090, \mathrm{p}=0.025)($ Table 4$)$.

Table 4. - Associations between location of authoring organization and perceived quality of knowledge, stratified by type of authority of authoring organization.

How the type of authority of authoring organization interacts with the location of these authorities in the prediction of reported instrumental use?

We found that the interaction between donor organizations and location was significant $(\beta=-1.110,95 \% \mathrm{Cl}=-1.779$ to $-0.441, \mathrm{p}=0.001)$ as was that between universities and location $(\beta=-1.053,95 \% \mathrm{Cl}=-1.740$ to $-0.366, p=0.003)$. Therefore, we performed a stratified analysis by type of authority of the authoring organization.

\section{Donor organization}

There were no significant differences by location for policy briefs signed by donor organizations. (Table 5). 
Table 5

Associations between location of authoring organization and reported instrumental use of knowledge, stratified by sector of authoring organization.

\begin{tabular}{|c|c|c|c|c|c|}
\hline & \multicolumn{5}{|c|}{ Reported instrumental use } \\
\hline & $\beta$ & {$[95 \% \mathrm{Cl}]$} & & & P-value \\
\hline \multicolumn{6}{|l|}{ Donor organizations (financial authority) } \\
\hline Intercept & 0.353 & -1.169 & ; 1.876 & ] & 0.642 \\
\hline \multicolumn{6}{|l|}{ Intervention } \\
\hline \multicolumn{6}{|l|}{ Location of authoring organization } \\
\hline Africa & REF & REF & REF & & REF \\
\hline Europe or North America & $-0,373$ & {$\left[\begin{array}{ll}{[} & -0,787\end{array}\right.$} & $; \quad 0,040$ & ] & 0,075 \\
\hline \multicolumn{6}{|l|}{ Confounding variable } \\
\hline \multicolumn{6}{|l|}{ Prior knowledge of the organization } \\
\hline Knows the organization & REF & REF & REF & & REF \\
\hline Does not know the organization & $-1,064$ & $-2,034$ & $; \quad-0,095$ & ] & $0,032 *$ \\
\hline Perceived autonomy in the profession & $-0,010$ & {$[\quad-0,172$} & $; \quad 0,152$ & ] & 0,897 \\
\hline Experience in the profession & 0,329 & {$[\quad 0,087$} & $; \quad 0,571$ & ] & $0,009 *$ \\
\hline \multicolumn{6}{|l|}{ Gender } \\
\hline Female & REF & REF & REF & & REF \\
\hline Male & 0,582 & {$[\quad 0,147$} & $; \quad 1,017$ & ] & $0,010 *$ \\
\hline \multicolumn{6}{|l|}{ Profession } \\
\hline Research professionals & REF & REF & REF & & REF \\
\hline Health professionals & 0,505 & $-0,255$ & $; \quad 1,265$ & ] & 0,187 \\
\hline Coordination/management of programs & 0,124 & {$[\quad-0,478$} & ; $\quad 0,726$ & ] & 0,681 \\
\hline Other & $-0,288$ & {$[\quad-0,975$} & ; $\quad 0,399$ & ] & 0,403 \\
\hline \multicolumn{6}{|l|}{ Level of study } \\
\hline University level postgraduate (PhD) & REF & REF & REF & & REF \\
\hline University level less than or equal to 1 st cycle & 0,279 & {$\left[\begin{array}{ll}0,369 \\
-1\end{array}\right.$} & $; \quad 0,928$ & ] & 0,390 \\
\hline University level 2nd cycle (MD) & 0,429 & {$[\quad-0,028$} & ; $\quad 0,887$ & ] & 0,065 \\
\hline \multicolumn{6}{|l|}{ Region of graduation } \\
\hline Africa & REF & REF & REF & & REF \\
\hline Europe or North America & $-1,099$ & {$\left[\begin{array}{ll}-1,541 \\
-\end{array}\right.$} & $; \quad-0,658$ & ] & $0,000 *$ \\
\hline \multicolumn{6}{|l|}{ Universities (scientific authority) } \\
\hline Intercept & -0.999 & {$\left[\begin{array}{ll}-2.314 \\
-\end{array}\right.$} & ; $\quad 0.317$ & ] & 0.134 \\
\hline \multicolumn{6}{|l|}{ Intervention } \\
\hline \multicolumn{6}{|l|}{ Location of authoring organization } \\
\hline Africa & REF & REF & REF & & REF \\
\hline Europe or North America & 0,670 & {$[\quad 0,150$} & ; $\quad 1,190$ & ] & $0,013 *$ \\
\hline \multicolumn{6}{|l|}{ Confounding variable } \\
\hline \multicolumn{6}{|l|}{ Prior knowledge of the organization } \\
\hline Knows the organization & REF & REF & REF & & REF \\
\hline
\end{tabular}




\begin{tabular}{|c|c|c|c|c|c|c|c|}
\hline \multirow[b]{2}{*}{ Does not know the organization } & \multicolumn{7}{|c|}{ Reported instrumental use } \\
\hline & $-0,038$ & {[} & $-0,596$ & ; & 0,520 & ] & 0,893 \\
\hline Perceived autonomy in the profession & 0,183 & {[} & $-0,036$ & ; & 0,403 & ] & 0,100 \\
\hline Experience in the profession & $-0,057$ & {[} & $-0,291$ & ; & 0,177 & ] & 0,626 \\
\hline \multicolumn{8}{|l|}{ Gender } \\
\hline Female & REF & & REF & & REF & & REF \\
\hline Male & 0,185 & {[} & $-0,445$ & ; & 0,814 & ] & 0,559 \\
\hline \multicolumn{8}{|l|}{ Profession } \\
\hline Research professionals & REF & & REF & & REF & & REF \\
\hline Health professionals & 0,514 & {[} & $-0,295$ & ; & 1,323 & ] & 0,208 \\
\hline Coordination/management of programs & $-0,024$ & {[} & $-0,703$ & ; & 0,656 & ] & 0,945 \\
\hline Other & 0,190 & {[} & $-0,543$ & ; & 0,923 & ] & 0,606 \\
\hline \multicolumn{8}{|l|}{ Level of study } \\
\hline University level postgraduate (PhD) & REF & & REF & & REF & & REF \\
\hline University level less than or equal to 1 st cycle & 0,316 & {[} & $-0,677$ & ; & 1,309 & ] & 0,526 \\
\hline University level 2nd cycle & 0,017 & {[} & $-0,557$ & ; & 0,590 & ] & 0,954 \\
\hline Region of graduation & & & & & & & \\
\hline Africa & REF & & REF & & REF & & REF \\
\hline Europe or North America & $-0,530$ & {[} & $-1,229$ & ; & 0,169 & ] & 0,134 \\
\hline \multicolumn{8}{|c|}{ Regional offices of international organization (moral authority) } \\
\hline Intercept & 0.980 & {[} & -0.209 & ; & 2.170 & ] & 0.104 \\
\hline \multicolumn{8}{|l|}{ Intervention } \\
\hline \multicolumn{8}{|l|}{ Location of authoring organization } \\
\hline Africa & REF & & REF & & REF & & REF \\
\hline Europe or North America & $-0,458$ & {[} & $-0,907$ & ; & $-0,009$ & ] & $0,046 *$ \\
\hline \multicolumn{8}{|l|}{ Confounding variable } \\
\hline \multicolumn{8}{|l|}{ Prior knowledge of the organization } \\
\hline Knows the organization & REF & & REF & & REF & & REF \\
\hline Does not know the organization & $-0,225$ & {[} & $-0,808$ & ; & 0,357 & ] & 0,439 \\
\hline Perceived autonomy in the profession & $-0,010$ & {[} & $-0,193$ & ; & 0,174 & ] & 0,915 \\
\hline Experience in the profession & $-0,368$ & {[} & $-0,595$ & ; & $-0,140$ & ] & $0,002^{*}$ \\
\hline \multicolumn{8}{|l|}{ Gender } \\
\hline Female & REF & & REF & & REF & & REF \\
\hline Male & 0,470 & {[} & 0,064 & ; & 0,877 & ] & $0,024 *$ \\
\hline \multicolumn{8}{|l|}{ Profession } \\
\hline Research professionals & REF & & REF & & REF & & REF \\
\hline Health professionals & 0,962 & {[} & 0,287 & ; & 1,637 & ] & $0,006 *$ \\
\hline Coordination/management of programs & 0,107 & {[} & $-0,391$ & ; & 0,604 & ] & 0,668 \\
\hline Other & 0,714 & [ & 0,017 & ; & 1,412 & ] & $0,045^{*}$ \\
\hline
\end{tabular}




\begin{tabular}{|c|c|c|c|c|c|c|c|}
\hline & \multicolumn{7}{|c|}{ Reported instrumental use } \\
\hline University level postgraduate (PhD) & REF & & REF & & REF & & REF \\
\hline University level less than or equal to 1 st cycle & 0,449 & [ & $-0,120$ & ; & 1,018 & ] & 0,119 \\
\hline University level 2nd cycle & 0,060 & {[} & $-0,505$ & ; & 0,625 & ] & 0,832 \\
\hline Region of graduation & & & & & & & \\
\hline Africa & REF & & REF & & REF & & REF \\
\hline Europe or North America & $-0,357$ & [ & $-0,852$ & ; & 0,138 & ] & 0,154 \\
\hline
\end{tabular}

University

The second stratified model revealed that perceived quality was stronger for participants who received the policy briefs signed by the North American/European university compared to those who received the policy briefs signed by the African university $(\beta=0.670,95 \% \mathrm{Cl}=0.150$ to 1.190, $\mathrm{p}=0.013$ ) (Table 5).

International organization

The third stratified model revealed that perceived quality was lower for participants who received the policy notes signed by the North American/European regional office of the international organization compared to those who received the policy notes signed by the African regional office of the international organization $(\beta=-0.458,95 \% \mathrm{Cl}=-0.907$ to $-0.009, \mathrm{p}=0.046)$ (Table 5).

Table 5. - Associations between location of authoring organization and reported instrumental use of knowledge, stratified by type of authority of authoring organization.

\section{Discussion}

\section{Summary of results}

Initial linear regression models showed that the type of authority (financial, scientific, moral) and the location (North America / Europe, Africa) of the policy brief authoring organization were not significantly associated with perceived quality and reported instrumental use.

Stratified analyses highlighted that policy briefs signed by the North American/European donor organization were perceived to be of lower quality than policy briefs signed by the African donor organization. For both perceived quality and reported instrumental use, these analyses found that policy briefs signed by the North American/European university were associated with higher scores than policy briefs signed by the African university whereas policy briefs signed by the North American/European regional office of international organization were associated with lower score than those signed by the African regional office of the international organization.

With respect to social characteristics, results show that graduate participants perceived higher quality and reported more use of policy briefs than postgraduate participants, as did participants who graduated in North America/Europe compared to those who graduated in Africa. For reported use, the results show that men reported more use than women, as well as health professionals compared to research professionals.

\section{Reputation heuristics and unfair evaluation of knowledge?}

We believe that "reputation heuristics", which have been studied in other contexts, can lead to unfair evaluation of online information (46). When considering the use of knowledge in the political sector, knowledge may be evaluated on the basis of the author's reputation (52) or the degree of agreement with the author (48) rather than the knowledge content.

We saw that the knowledge contained in policy briefs signed by North American/European organizations was, in the majority, perceived to be of lower quality than those signed by African organizations, except for the universities. It is possible that the assessment of knowledge was based on a certain distrust of external interventions in health policy in francophone Africa. Indeed, the involvement of donor and international organizations in francophone Africa is strongly criticized. On the one hand, the financial and political stakes raise questions about the values underlying the interventions of external countries in this area. On the other hand, the lack of knowledge of the field contribute to questioning their legitimacy (53). There is also a major issue with knowledge and experience capitalization to promote learning and improve practices (54). Indeed, "development" relations in francophone Africa are strongly related to foreign ministries orientations, which include geopolitical issues, but also sometimes, the goodwill of ministers in place. There are distrusts about the links between policy and knowledge production $(55,56)$ 
(and this was emphased with the knowledge mobilization processes for the fight against COVID-19) and about the intervention of development agencies in this region, which could undermine the perceived quality of the policy briefs signed by the latter. There is also a decline in international organizations authority such as WHO that may participate in the decline in trust among external representations of these organizations $(20,21)$.

We also saw that knowledge contained in policy briefs signed by the North American/European university was perceived to be of higher quality than those signed by the African university. African universities, suffering from a lack of public investment, may be victims of a decline in scientific authority (57). The low recognition of francophone African universities in scientific activities is often due to (among other things) a lack of professors and researchers, a lack of doctoral training, and a lack of social recognition of the research activity (58-60). The generalization of the low recognition of knowledge production or research activity in francophone African universities can lead to a vicious circle between interpretative, testimonial, and social injustices. Indeed, because of their low capacity to mobilize financial resources and their weak international influence, francophone African universities have little influence on the agendas of global governance. They "participate in the 'international division of competencies' by occupying the position of executors rather than leaders of the international research agenda" (60). Thus, these universities experience inequalities in access and knowledge production on the global stage (39). They also experience challenges in legitimizing the knowledge they can produce, as we experience in this study, but which is also analyzed in others (57, 59, 61, 62).

\section{A "monetary" use of knowledge?}

While the policy briefs signed by the North American/European donor organization were perceived as being of lower quality, they were not reported as being less used than the policy briefs signed by the African donor organization. This may be explained by the idea that knowledge presented by organizations with financial authority is more useful in advancing an idea, putting an issue on the agenda, or organizing resistance to a policy (63), particularly in the "development arena" (64). Indeed, often referred to as "technical and financial partners" donor and international organizations participate in national health committees in francophone African countries (65), in the same way as national organizations, which gives them power in the development of health policies. At the same time, universities are being supplanted by consultancy activities in the production of knowledge $(59,61,62,66)$, which contributes to the decline of the monetary value of the knowledge produced by universities. While this "monetization" of knowledge use can strengthen the authorities of dominant organizations, even if the quality of knowledge is perceived as poor, it is detrimental to organizations that do not have financial or moral power. It can create a reinforcement of the intersectionality of normative, financial, and epistemic powers.

\section{Limits and implications for knowledge translation}

It would be useful to complement this quantitative analysis with a qualitative study to compare the explanations given by stakeholders for these results. Indeed, this study is exploratory, and it is still difficult to propose rigorous explanations of the results. In addition, this study was offered online in a context where containment measures during the COVID-19 pandemic were being implemented in several countries. Currently, the flow of information via digital means has increased. Participants may not have taken the necessary care to complete the questionnaire thoroughly. The topic of containment effectiveness was chosen intentionally to increase the willingness of the individuals contacted to participate. The method of contact, through mailing lists and focal points, may also have had an impact on the sample, which is not as diverse as if participants had been contacted through national sampling frames or institutional directories. It is also possible that the fact that the first author of this analysis presented herself as a doctoral student and member of a northern research institute to increase participation in the survey may have influenced the perceived source of the policy briefs. It would have been very interesting to increase the number of scenarios with a larger number of organizations, but the number of participants would not have allowed for statistically sound analyses.

This analysis permits us to both learn more about organizations in global health leadership and to reflect on the implications for knowledge translation practices. We have seen that participants with their highest degree from African universities are more likely to report using knowledge than those with their highest degree from institutions in Europe or North America, as well as men versus women or graduate versus postgraduate. This difference in attitude could be better understood through further qualitative analysis. This could allow us to try to adapt strategies that consider the rationalities of individuals according to their social characteristics, rather than strategies by context, without considering the differences between social groups (67). In addition, a larger number of participants would have been relevant to conducting interactions between regions of education, gender, and authoring organizations to better understand how and why individuals use or do not use knowledge and the dynamics with organizational authority issues in the global health context.

\section{Conclusion}

The results confirm the significant influence of sources on perceived global health knowledge. The influence of social characteristics on perceptions of quality and statements of use allows us to see different relationships with knowledge depending on the social group. This study is exploratory, and further analysis would be useful to better understand the dynamics between authoring organization representation, perceived quality, and statements of use to take them into account in knowledge translation strategies. 


\section{Declarations}

\section{Ethics approval and consent to participate}

When the invitation to participate in the survey was emailed out, there was a link to read the tool presented and take a questionnaire on the WIX platform that helps secure data in connection with the General Data Protection Regulation (GDPR). The GDPR aims to protect the fundamental right to privacy and personal data protection of European Union (EU) citizens. To avoid bias in the experiment, two information and consent forms are presented at the beginning and end of the experiment. The latter mentioned the link to the basic policy note, without modifying the organizations presented as authors but also the real objective of the study, which was not presented in the first questionnaire. At the end of the second information form, the participant could click on "accept" or leave the page if they did not want their data to be used. No data were recorded without the participant clicking the "accept" button. This study is part of a thesis for which the protocol was submitted to the Health and Science Research Ethics Committee of the University of Montreal. The final certificate was obtained on June 17, 2020 (CERES-18127-D).

\section{Consent for publication}

Not applicable.

\section{Availability of data and materials}

The datasets generated and/or analyzed during the current study are not publicly available due to the necessity of authoring organization anonymity but are available from the corresponding author on reasonable request.

\section{Competing interests}

Most authors work on project financing by a European donor organization and are members (students, professors) of universities. That could influence scientific processes. However, diversifying among organizations is a way to diminish these influences as well as the anonymity of authoring organizations in this article. The authors declare that they have no competing interests.

\section{Funding}

The research project is part of the UNISSAHEL program (Universal Health Coverage in Sahel), funded by the Agence Française de développement (AFD) Group.

\section{Authors' contributions}

The idea for the article was put forward by VR, CD and AF. The design of the method was discussed by the same three people, BV, KK and EMS, and then implemented by AF and EMS. The recruitment of participants was mainly done by VR and AF. Data were collected and analyzed by AF, UBNK, MPL and BV. The analysis proposals were discussed among the different authors. The first draft was written by AF and reread and commented on by the coauthors several times before final submission to the journal.

\section{Acknowledgments}

This study would not have been successful without the contributions of all Unissahel project members and all the people who participated in the "snowball effect" for disseminating the study. We truly thank them for having made this study possible. We also thank Dr. Sedric Degbo, who disseminated the study through his platform that centralizes West African health professionals (www.remaapp.com).

\section{References}

1. Abimbola S, Asthana S, Montenegro C, Guinto RR, Jumbam DT, Louskieter L, et al. Addressing power asymmetries in global health: Imperatives in the wake of the COVID-19 pandemic. PLOS Med. 22 avr 2021;18(4):e1003604.

2. Barnett M, Duvall R. Power in Global Governance. 2005;391.

3. Forman L. The Ghost Is the Machine: How Can We Visibilize the Unseen Norms and Power of Global Health? Comment on « Navigating Between Stealth Advocacy and Unconscious Dogmatism: The Challenge of Researching the Norms, Politics and Power of Global Health ». 
Int J Health Policy Manag. 3 déc 2015;5(3):197-9.

4. Shiffman J. Knowledge, moral claims and the exercise of power in global health. Int J Health Policy Manag 8 nov. 2014;3(6):297-9.

5. Shiffman J. Global Health as a Field of Power Relations: A Response to Recent Commentaries. Int J Health Policy Manag 22 mai. 2015;4(7):497-9.

6. Engebretsen E, Heggen K. Powerful concepts in global health Comment on « Knowledge, moral claims and the exercise of power in global health ». Int J Health Policy Manag. 31 janv 2015;4(2):115-7.

7. Hanefeld J, Walt G. Knowledge and networks - key sources of power in global health. Int J Health Policy Manag 5 févr. 2015;4(2):119-21.

8. Shiffman J. Networks and global health governance: Introductory editorial for Health Policy and Planning supplement on the Emergence and Effectiveness of Global Health Networks. Health Policy Plan avr. 2016;31(Suppl 1):i1-2.

9. Horton R, Offline. The pretensions of global health elites. The Lancet 29 févr. 2020;395(10225):672.

10. Bhakuni H, Abimbola S. Epistemic injustice in academic global health. Lancet Glob Health [Internet]. 9 août 2021 [cité 30 août 2021$] ; 0(0)$. Disponible sur: https://www.thelancet.com/journals/langlo/article/PIIS2214-109X(21)00301-6/abstract.

11. Fricker M. Epistemic Injustice: Power and the Ethics of Knowing. Oxford University Press; 2007.

12. Lauer H. How epistemic injustice in the global health arena undermines public health care delivery in Africa. In Rio de Janeiro; 2017. p. 24.

13. Dalglish SL. COVID-19 gives the lie to global health expertise. The Lancet 11 avr. 2020;395(10231):1189.

14. Sanz-Menéndez L, Cruz-Castro L. The credibility of scientific communication sources regarding climate change: A population-based survey experiment: Public Underst Sci [Internet]. 17 avr 2019 [cité 18 avr 2020]; Disponible sur: https://journals.sagepub.com/doi/10.1177/0963662519840946?url_ver=Z39.88-

2003\&rfr_id=ori\%3Arid\%3Acrossref.org\&rfr_dat=cr_pub\%3Dwww.ncbi.nlm.nih.gov.

15. Michalovich A, Hershkovitz A. Assessing YouTube science news' credibility: The impact of web-search on the role of video, source, and user attributes. Public Underst Sci. 19 févr 2020;0963662520905466.

16. Beynon P, Chapoy C, Gaarder M, Masset E. What Difference does a Policy Brief Make? 2012 p. 115.

17. Javdani M, Chang H-J. Who Said or What Said? Estimating Ideological Bias in Views Among Economists [Internet]. Canada: University of British Columbia; 2019. https://mpra.ub.uni-muenchen.de/91958/1/MPRA_paper_91958.pdf. [cité 22 avr 2019. Disponible sur.

18. Birn A-E. Philanthrocapitalism, past and present: The Rockefeller Foundation, the Gates Foundation, and the setting(s) of the international/global health agenda. Hypothesis [Internet]. 1 nov 2014 [cité 16 juin 2020];12(1). Disponible sur: http://www.hypothesisjournal.com/?p=2503.

19. Fillol A, Ridde V. Gouvernance globale et utilisation des connaissances pour l'action: Rev Francoph Rech Sur Transf L'utilisation Connaiss [Internet]. 1 déc 2020 [cité 8 avr 2021];4(2). Disponible sur: https://revue-tuc.ca/index.php/accueil/article/view/15.

20. Hoffman SJ, Røttingen J-A. Split WHO in two: strengthening political decision-making and securing independent scientific advice. Public Health 1 févr. 2014;128(2):188-94.

21. Lee K. Pang (Pangestu) T. WHO: Retirement or Reinvention? Public Health févr. 2014;128(2):119-23.

22. Abimbola S. The foreign gaze: authorship in academic global health. BMJ Glob Health [Internet]. 18 oct 2019 [cité 20 nov 2020 ];4(5). Disponible sur: https://www.ncbi.nlm.nih.gov/pmc/articles/PMC6830280/.

23. Global Health 50/50. Power, privilege and priorities [Internet]. London; 2020 [cité 9 mars 2020]. Disponible sur: https://globalhealth5050.org/wp-content/uploads/2020/03/Power-Privilege-and-Priorities-2020-Global-Health-5050-Report.pdf.

24. Velin L, Lartigue J-W, Johnson SA, Zorigtbaatar A, Kanmounye US, Truche P, et al. Conference equity in global health: a systematic review of factors impacting LMIC representation at global health conferences. BMJ Glob Health. 1 janv 2021;6(1):e003455.

25. Dübgen F, Skupien S. New Approaches to Scientific Dependency and Extraversion: Southern Theory, Epistemic Justice and the Quest to Decolonise Academia. In: Dübgen F, Skupien S, éditeurs. Paulin Hountondji: African Philosophy as Critical Universalism [Internet]. Cham: Springer International Publishing; 2019 [cité 22 janv 2021]. p. 109-34. (Global Political Thinkers). Disponible sur: https://doi.org/10.1007/978-3-030-01995-2_6.

26. Ndofirepi A. African universities on a global ranking scale: Legitimation of knowledge hierarchies? South Afr J High Educ [Internet]. mars 2017 [cité 23 avr 2020];31(1). Disponible sur: http://www.journals.ac.za/index.php/sajhe/article/view/1071.

27. Tonda J. L'impossible décolonisation des sciences sociales africaines. Mouvements. 2012;72(4):108-19.

28. Gautier L, Karambé Y, Dossou J-P, Samb OM. Rethinking development interventions through the lens of decoloniality in sub-Saharan Africa: The case of global health. Glob Public Health 8 déc. 2020;0(0):1-14.

29. de Sousa Santos B. Beyond Abyssal Thinking: From Global Lines to Ecologies of Knowledges. Rev Fernand Braudel Cent. 2007;30(1):4589. 
30. Lavis JN, Permanand G, Oxman AD, Lewin S, Fretheim A. SUPPORT Tools for evidence-informed health Policymaking (STP) 13: Preparing and using policy briefs to support evidence-informed policymaking. Health Res Policy Syst 16 déc. 2009;7(Suppl 1):13.

31. Arnautu D, Dagenais C. Use and effectiveness of policy briefs as a knowledge transfer tool: a scoping review. A paraître.

32. Cash D, Clark WC, Alcock F, Dickson NM, Eckley N, Jäger J, Salience. Credibility, Legitimacy and Boundaries: Linking Research, Assessment and Decision Making [Internet]. Rochester, NY: Social Science Research Network; 2002 nov [cité 22 avr 2020]. Report No.: ID 372280. Disponible sur: https://papers.ssrn.com/abstract=372280.

33. Cash DW, Clark WC, Alcock F, Dickson NM, Eckley N, Guston DH, et al. Knowledge systems for sustainable development. Proc Natl Acad Sci 8 juill. 2003;100(14):8086-91.

34. Dunn G, Laing M. Policy-makers perspectives on credibility, relevance and legitimacy (CRELE). Environ Sci Policy 1 oct. $2017 ; 76: 146-52$.

35. Beyer JM, Trice HM. The Utilization Process: A Conceptual Framework and Synthesis of Empirical Findings. Adm Sci Q. 1982;27(4):591622.

36. Weiss. The many meanings of research. Public administration review. 1979;426-31.

37. Graham ID, Logan J, Harrison MB, Straus SE, Tetroe J, Caswell W, et al. Lost in knowledge translation: time for a map? J Contin Educ Health Prof. 2006;26(1):13-24.

38. Gautier L, Tosun J, De Allegri M, Ridde V. How do diffusion entrepreneurs spread policies? Insights from performance-based financing in Sub-Saharan Africa. World Dev 1 oct. 2018;110:160-75.

39. Affun-Adegbulu C, Adegbulu O. Decolonising Global (Public) Health: from Western universalism to Global pluriversalities. BMJ Glob Health 1 août. 2020;5(8):e002947.

40. Eichbaum QG, Adams LV, Evert J, Ho M-J, Semali IA, van Schalkwyk SC. Decolonizing Global Health Education: Rethinking Institutional Partnerships and Approaches. Acad Med J Assoc Am Med Coll. 28 avr 2020.

41. Godrie B, Dos Santos M. Présentation: inégalités sociales, production des savoirs et de l'ignorance. Sociol Sociétés. 2017;49(1):7-31.

42. Santos B de. S. Cognitive Justice in a Global World: Prudent Knowledges for a Decent Life. Lexington Books; 2007.472 p.

43. Hoffman SJ, Cole CB. Defining the global health system and systematically mapping its network of actors. Glob Health [Internet]. 17 avr 2018 [cité 29 avr 2020];14. Disponible sur: https://www.ncbi.nlm.nih.gov/pmc/articles/PMC5904998/.

44. Gaziano C, McGrath K. Measuring the Concept of Credibility. Journal Q 1 sept. 1986;63(3):451-62.

45. McCroskey JC, Holdridge W, Toomb JK. An instrument for measuring the source credibility of basic speech communication instructors. Speech Teach janv. 1974;23(1):26-33.

46. Metzger MJ, Flanagin AJ, Eyal K, Lemus DR, Mccann RM. Credibility for the 21st Century: Integrating Perspectives on Source, Message, and Media Credibility in the Contemporary Media Environment. Ann Int Commun Assoc janv. 2003;27(1):293-335.

47. Meyer P. Defining and Measuring Credibility of Newspapers: Developing an Index. Journal Q 1 sept. 1988;65(3):567-74.

48. Akerlof K, Lemos M, Cloyd E, Heath E. Who Isn't Biased? Perceived Bias as a Dimension of Credibility in Communication of Science with Policymakers. lowa State Univ Summer Symp Sci Commun [Internet]. 1 janv 2018; Disponible sur: https://lib.dr.iastate.edu/sciencecommunication/2018/proceedings/3.

49. Buljan I, Malički M, Wager E, Puljak L, Hren D, Kellie F, et al. No difference in knowledge obtained from infographic or plain language summary of a Cochrane systematic review: three randomized controlled trials. J Clin Epidemiol 1 mai. 2018;97:86-94.

50. Dagenais C, Ridde V. Policy brief as a knowledge transfer tool: to "make a splash", your policy brief must first be read. Gac Sanit [Internet]. 2018 [cité 4 avr 2018]; Disponible sur: https://www.sciencedirect.com/science/article/pii/S0213911118300360.

51. Jones N, Walsh C. Policy briefs as a communication tool for development research. Overseas development institute; 2008.

52. Delahais T, Lacouette-Fougère $C$. Try again. Fail again. Fail better. Analysis of the contribution of 65 evaluations to the modernisation of public action in France. Evaluation 1 avr. 2019;25(2):131-48.

53. Olivier de Sardan J-P. De Barkhane au développement: la revanche des contextes [Internet]. AOC media - Analyse Opinion Critique. 2021 [cité 22 juill 2021]. Disponible sur: https://aoc.media/analyse/2021/06/13/de-barkhane-au-developpement-la-revanche-des-contextes/.

54. Pacquement F. Histoire de l'Agence Française de Developpement en Cote d'Ivoire. Illustrated édition. Paris: Karthala; 2016.256 p.

55. Hughes CE. Evidence-based policy or policy-based evidence? The role of evidence in the development and implementation of the Illicit Drug Diversion Initiative. Drug Alcohol Rev juill. 2007;26(4):363-8.

56. Parkhurst JO. The politics of evidence: from evidence-based policy to the good governance of evidence. New York: Routledge;: Abingdon, Oxon; 2017.

57. Akam M. Le marché de l'expertise et la place du socio-anthropologue: le chercheur en sciences sociales en Afrique. Illustrations camerounaises. Bull APAD [Internet]. 1 juill 1994 [cité 2 déc 2021];(7). Disponible sur:

https://journals.openedition.org/apad/2293\#tocto1n4. 
58. Loua S. Efficacité interne de l'enseignement supérieur malien. [Lyon]:. Institut des Sciences et Pratiques d’Education et de Formation; 2012.

59. Makosso B. La crise de l'enseignement supérieur en Afrique francophone: une analyse pour les cas du Burkina Faso, du Cameroun, du Congo, et de la Côte d'Ivoire. J High Educ Afr Rev Enseign Supér En Afr. 2006;4(1):69-86.

60. Marou Sama KM. Les carrières des chercheurs et les politiques d'enseignement supérieur et de recherche au Niger. [Paris]: Université ParisEst; 2016.

61. Kuditshini JT. Mondialisation et développement démocratique: vers la re-légitimation du rôle du secteur public de la recherche scientifique et technique en Afrique. In: Les réformes du secteur public en République démocratique du Congo. Codesria. Dakar; 2013. p. 58.

62. Yapi-Diahou A. Research and the challenge of expertise in Africa. CODESRJA Bulletin. 2005;(4):3.

63. Ingold J, Monaghan M. Evidence translation: an exploration of policy makers' use of evidence. Policy Polit 25 avr. 2016;44(2):171-90.

64. Olivier De Sardan J-P. Anthropologie et développement. Essai en socio-anthropologie du changement social. [Internet]. Karthala. Paris; 1995 [cité 25 oct 2017]. (Hommes et sociétés). Disponible sur:

http://classiques.uqac.ca/contemporains/olivier_de_sardan_jean_pierre/anthropologie_et_developpement/anthropo_et_developpement.pdf.

65. Moha M, Ridde V. La conférence nationale sur la gratuité des soins au Niger: des interactions nécessaires. Une Polit Publique Santé Ses Contradict Gratuité Soins Au Burkina Faso Au Mali Au Niger. 2014;472.

66. Olivier de Sardan J-P. Promouvoir la recherche face à la consultance. Autour de l'expérience du LASDEL (Niger-Bénin). Cahiers d'Études africaine. 2011;511-28.

67. Lapalme J, Haines-Saah R, Frohlich KL. More than a buzzword: how intersectionality can advance social inequalities in health research. Crit Public Health 7 août. 2020;30(4):494-500.

\section{Table}

Table 4 is not available with this version

\section{Supplementary Files}

This is a list of supplementary files associated with this preprint. Click to download.

- Additionalfile1DESKTOP6BICH2H.pdf

- Additionalfile2.pdf

- Additionalfile3.pdf

- Additionalfile4.pdf

- Additionalfile5.pdf 